\title{
Small mammals of some undeveloped area in Saint-Petersburg
}

\author{
Irina M. Gorbunova \& Kirill A. Tretyakov
}

\begin{abstract}
The specific structure and number of small mammals on 31 localities of undeveloped territories of Saint-Petersburg was investigated. In total 2648 small mammals belonging to 13 species were trapped. Their diversity increases from the centre of town to periphery. Majority of species were found in parks and urbanized forests located in city's peripherals whereas the maximum amount of species per station did not exceed eight. The most abundant species were field mice Apodemus agrarius (Pallas, 1771) and bank voles Myodes glareolus (Schreber, 1780).
\end{abstract}

KEY WORDS: small mammals, biodiversity, density of population.

Irina M. Gorbunova [irishg@yandex.ru], Anti-Plague Station of Saint-Petersburg, Nevelskaya str. 3, Saint Petersburg 198035, Russia; Kirill A. Tretyakov [k-sanych@yandex.ru], Zoological Institute, Russian Academy of Sciences, Universitetskaya nab. 1, Saint-Petersburg 199034, Russia.

\section{Мелкие млекопитающие незастроенных территорий Санкт-Петербурга}

\section{И.М. Горбунова, К.А. Третьяков}

\begin{abstract}
РЕЗЮМЕ. Исследован видовой состав и численность мелких млекопитающих на 31 участке незастроенных территорий Санкт-Петербурга. Было отловлено 2648 мелких млекопитающих, относящихся к 13 видам. Число видов увеличивалось от центра города к периферии. Максимальное число видов обнаружено в лесах и парках на периферии города и не превышало 8. Наиболее многочисленными были полевая мышь Apodemus agrarius (Pallas, 1771) и рыжая полевка Myodes glareolus (Schreber, 1780).
\end{abstract}

КЛЮЧЕВЫЕ СЛОВА: мелкие мЛекопитающие, биологическое разнообразие, численность мелких млекопитающих.

\section{Introduction}

The XX century was marked by a rapid growth of cities, where Saint-Petersburg can be considered as a good example. In the case of Saint-Petersburg, former suburbs became vibrant parts of the city and forests shrank to mere green belts. Most of them are densely populated today. However, at the same time they preserved some features rather typical for natural biotopes. Some agricultural areas became urban as well and show signs of increasing vegetation.

Since 1950 s, several studies were conducted on populations of small mammals in urbanized areas (Poyarkov, 1956; Fomushkin, 1967), mostly in Moscow (Karaseva et al., 1990; Tikhonova et al., 1997, 2002, 2004). Earlier studies were predominantly dealing with qualitative distribution of species in cities (Klausnitzer, 1982; Sukopp, 1983). Moscow was divided in several areas, from downtown to the outset limits of the city (Karaseva et al., 1990).

Tikhonova et al. (1997) suggested a more distinct classification and proposed 15 types of suburbanized areas. The classification is based on a gradient (A-E) reflecting different transition patterns among areas. We also claim that Saint-Petersburg can be divided into similar areas spanning historical as well as new parts of the city (including former suburbs).

Saint-Petersburg became subject to studies on small mammals in 1960-1970s (Kluchnik \& Starostina, 1963; Vaschenok et al., 1973; Liutov et al., 1977) while distribution and reproduction patterns were closely examined. Some data were provided in the book series "Protected areas of Saint-Petersburg", however these data are mostly qualitative. Currently, some blatant changes occurred in Saint-Petersburg which merit new studies. In this paper, we concentrate on distribution patterns of small mammals in suburbanized areas of Saint Petersburg.

\section{Material and methods}

Rodents were trapped since 2006 until 2010 on 31 plots in total (Fig. 1). Following areas were examined: forest near the Lake Razliv, near of railway station Morskaya, near settlements Verevo, Sashino, Lisiy Nos, Sestroretsk, near the Northern and Southern cemeteries, forest-parks (Rzhevsky, Udelny, Untolovsky, Shuvalovsky, Shungerovsky, Sosnovsky, and Nevsky), parks (Ekateringofsky, Forestry Academy (LTA Park) and Pavlovsky, Aleksandrino, Sosnovaya Polyana, Botani- 


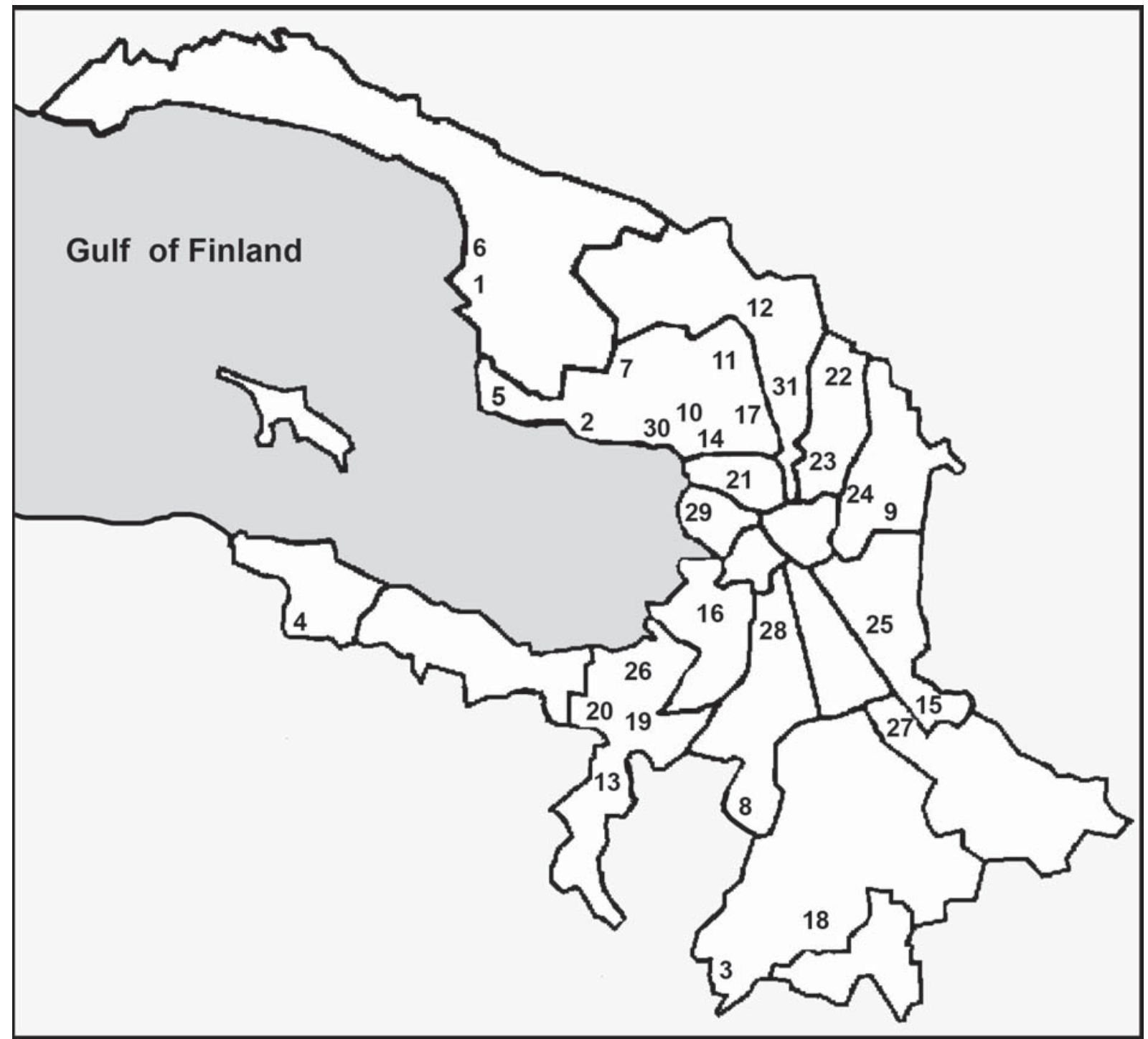

Figure 1. Plan of Saint-Petersburg with city districts. Studied areas: forest near Lake Razliv (1); vicinity of railway station Morskaja (2); vicinity of settlements: Verevo (3), Sashino (4), Lisiy Nos (5), Sestroretsk (6); areas around the Northern (7) and Southern cemeteries (8); forest-parks: Rzhevsky (9), Udelny (10), Untolovsky (11), Shuvalovsky (12), Shungerovsky (13), Sosnovsky (14), Nevsky (15), parks: Ekateringofsky (16), Forestry Academy (LTA park) (17), Pavlovsky (18); Aleksandrino (19), Sosnovaya Polyana (20), Botanical Garden of the Botanical Institute RAS (21); the territory of the cemeteries: the Crematorium (22), Okhtinskoe (23), Porohovskoe (24), Konovievskoe (25), Krasnenkoe (26), Victims of the Ninth January (27), Volkovskoe (28), Smolenskoe (29), Serafimovskoe (30), Bogoslovskoe (31).

cal Garden of Botanical Institute of RAS, Biological Institute of Saint-Petersburg State University, the territory of cemeteries (the Crematorium, Okhtinskoe, Porohovskoe, Konovievskoe, Krasnenkoe, Victims of the Ninth January, Volkovskoe, Smolenskoe, Serafimovskoe, and Bogoslovskoe). In total of 14150 trapnights were conducted and 2648 small mammals of 13 species were trapped (Tab. 1).

Different diversity indices (Margalef, Simpson and Berger-Parker indices) have been used to describe the species diversity (Magurran, 1992).

\section{Results and discussion}

The examined areas of the city can be clustered into four groups. Group 1 consists of peripheral forests and parks: forest near Lake Razliv, near railway station Morskaya, near the Northern and Southern cemeteries, Rzhevsky, Shungerovsky and Nevsky forest-parks. These areas are most closely related to natural forests and have connections to not-urbanized areas. The density of human population is quite low with parks being by far less dominant than forests. There are also parks 
Table 1. Mammals trapped in Saint-Petersburg during 2006-2010.

\begin{tabular}{|c|l|c|c|}
\hline No & \multicolumn{1}{|c|}{ Species } & Number of caught animals & Species amount (\%) \\
\hline 1 & Sorex araneus, common shrew & 510 & 19.3 \\
\hline 2 & Sorex minutus, pygmy shrew & 47 & 1.8 \\
\hline 3 & Sorex caecutiens, Laxmann's shrew & 3 & 0.1 \\
\hline 4 & Apodemus uralensis, Ural field mouse & 164 & 6.2 \\
\hline 5 & Apodemus agrarius, black-striped field mouse & 859 & 32.4 \\
\hline 6 & Apodemus flavicollis, yellow-necked mouse & 64 & 2.4 \\
\hline 7 & Mus musculus, house mouse & 3 & 0.1 \\
\hline 8 & Micromys minutus, harvest mouse & 4 & 0.2 \\
\hline 9 & Myodes glareolus, bank vole & 936 & 35.3 \\
\hline 10 & Microtus agrestis, short-tailed vole & 40 & 1.5 \\
\hline 11 & $\begin{array}{l}\text { Microtus ex. gr. arvalis } \text { (Microtus arvalis, Microtus } \\
\text { rossiaemeridionalis), common vole }\end{array}$ & 1 & 0.0 \\
\hline 12 & Rattus norvegicus, Norway rat & 14 & 0.5 \\
\hline 13 & Sicista betulina, northern birch mouse & 3 & 0.1 \\
\hline
\end{tabular}

that are similar to forests in their look and can be found in different parts of the city. The most part of the forest parks are derivative small-leaved forests of middle age, sometimes spruce, birch-spruce, pine and broad-leaved forest fragments (Tikhonova et al., 1997).

Group 2 consists of forests and parks located on peripherals of the city in suburbanised areas surrounded by buildings (Yuntolovsky, Udelny, and Sosnovski parks, parks of Pavlovsk, Alexandrino, and Sosnovaya Polyana). We are dealing in this case with medium to large size biotopes that are not subject to a heavy urban load. Those areas originated from natural forests assimilated by the city extended by artificially planted parks on natural soils. We are dealing with dynamic ecosystems adapted to urban load while still keeping some features of the natural forests (Tikhonova et al., 1997). The floristic composition of this group is more diverse then the same compositions of first group of parks. The stand of trees is composed of lime-trees, poplars, birches, maples, oaks, aspens, elms and coniferous. The undergrowth is developed well. Grass layer is similar to that found in natural forests but is more resistant to urban load, with species like lupine, goldenrod, and columbine.

Group 3 consists of small parks located close to downtown with a long history of urbanisation (Ekateringofsky, Forestry Academy and the Botanical Garden of the Botanical Institute of RAS). The most distinctive features they share include small surfaces and strong isolation patterns. These areas are subject to heavy urban load and originate from older (older than 50 years) and newer parks, usually with natural soils. Vegetation is not well developed and grass layer is tiny or may be absent in some places (Tikhonova et al., 1997). The stand of trees is composed poplars, lime-trees, maples, elms, ash-trees, larches, and spruces.

Group 4 consists of the cemeteries (Crematorium, Okhtinskoe, Porohovskoe, Konovievskoe, Krasnenkoe, Victims of the Ninth January, Volkovskoye, Smolenskoe, Serofimovskoe, and Bogoslovskoe). It is rather a variable group with cemeteries defined by their locali- sation and proximity to downtown, located on natural soils. This group shares many features with parks while being subject to unique patterns of urban load: due to the emotional component, the cemeteries are rarely visited by inhabitants. Scarce or absent grass layers are rather norms and more often than not originate from artificial planting. However, vegetation can show high diversity of species being utilised as food by small mammals. Maples, lime-trees, ash-trees, poplars, birches and mountain ashes are often found in the stands. Lilacs, Spiraea sp., honeysuckles, mock oranges, high cranberries dominate in the shrub layer.

All small mammals captured can be divided into three groups (Tikhonova et al., 2009): 1 - synanthropic (house mouse and Norway rat), 2 - optional synanthropic (field mouse, small wood mouse, and common vole), 3 - false synanthropic (bank vole, common shrew, and rare species for the city). The most common species were bank voles $(35.3 \%)$ and the field mice $(32.4 \%)$. The next abundant was common shrew (19.4\%). The share of other species is $13 \%$.

Most species were found in the parks and urbanised forests located on city's peripherals whereas the maximal amount of species per station did not exceed eight. Bank vole was the most numerous $(58 \%$ of the total number of trapped animals). Common shrew ranked second $(17.1 \%)$. Shares of small wood mouse and field mouse are approximately equal (8.7 and 7.5, respectively). Rare for the Leningrad Province species (northern birch mouse, short-tailed vole) are found only there. The presence of synanthropic species can be explained by the proximity of the buildings in some habitats. Synanthropic species are represented by single specimens.

Six species were reported from parks and urbanized forests surrounded by residential areas. Common shrew was the most abundant species $(51.9 \%)$. Proportion of field mice has increased up to $25.9 \%$. Bank voles were spotted only in localities similar to natural forest with small urban load. Synanthropic species were not caught.

Only three species of small mammals were found in city parks, and field mouse being a dominant species 
Table 2. The indices of species diversity of small mammals in the undeveloped areas of Saint-Petersburg.

\begin{tabular}{|c|c|c|c|}
\hline \multirow{2}{*}{$\begin{array}{c}\text { The group } \\
\text { of stations }\end{array}$} & \multicolumn{3}{|c|}{ Indices } \\
\cline { 2 - 4 } & $\begin{array}{c}\text { Berger-Parker } \\
\text { index }\end{array}$ & $\begin{array}{c}\text { Margalef } \\
\text { index }\end{array}$ & $\begin{array}{c}\text { Simpson } \\
\text { index }\end{array}$ \\
\hline 1 & 0.58 & 4.15 & 0.38 \\
\hline 2 & 0.52 & 1.89 & 0.36 \\
\hline 3 & 0.99 & 0.58 & 0.98 \\
\hline 4 & 0.87 & 1.54 & 0.76 \\
\hline
\end{tabular}

(98-100\%). The Norway rat and common vole were very scarce.

Six species of small mammals were spotted on city cemeteries, field mouse being a dominant species. House mouse and rat were very scarce. The highest density was found in the Smolenskoe Cemetery, located in downtown. Optional and false synanthropic species have higher density in peripheral areas of the city.

Highest species diversity was typical for forests and urbanized forests located outside of the residential areas (see Tab. 2). At the same time, diversity was lower in forests and urbanized forests located inside residential areas and in cemeteries. Small parks located close to downtown showed the lowest diversity ever. Dominance was at its peak in small parks and on cemeteries. This fact can be attributed to having one species with the highest competitive advantages and, thus, being the most adapted to the areas under consideration. The distribution of species abundance is close to geometric distribution. Dominance was considerably lower among small mammals in parks and urbanized parks located at the peripherals of the city. The distribution is close to lognormal distribution that is inherent in small mammal communities of mixed forests (Tikhonova et al., 2009). Dominance was more distinct in parks and forests. This fact can be explained by high numbers of bank vole in some areas.

Similarity measures (based on Euclidean distances) point to the closeness of community species composition and abundance of animals of forests and parks, located on the periphery of the city, and their considerable isolation from small parks and cemeteries (Fig. 2). Communities of small mammals in the forest-parks have preserved more resemblance to the natural forest communities than the population of rodents and insectivores that live in areas prone to strong anthropogenic influence.

\section{Conclusion}

Small city parks can be deemed to be the least favourable for small mammals with cemeteries offering a slightly more favourable environment. In those cases usually one species clearly dominates. False synanthropic species recorded in the habitats of this type. Some parks located at the city peripherals are similar to natural forests in respect to their populations of small

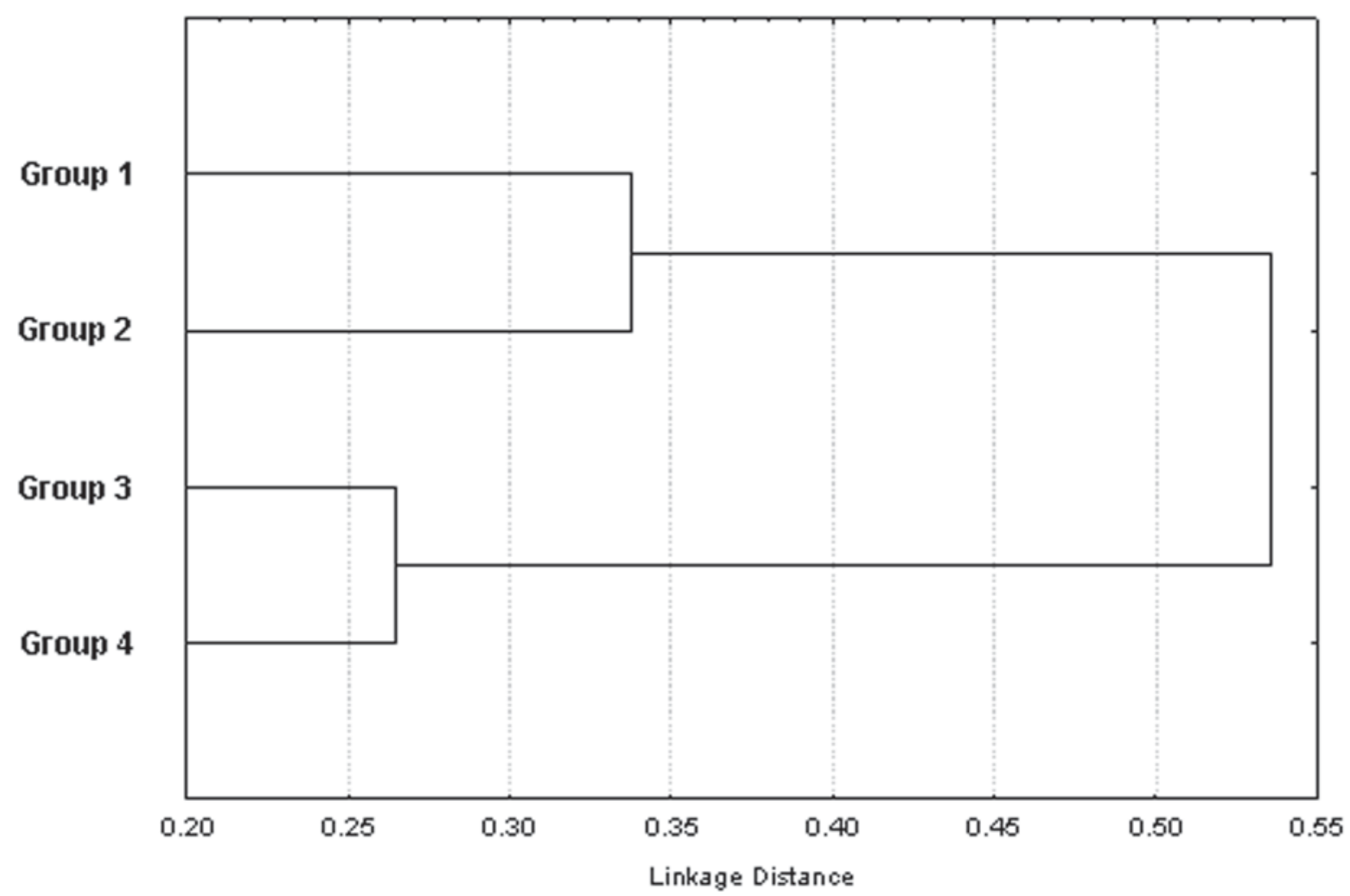

Figure 2. Single-linkage dendrogram of similarity of small mammal communities in different areas of Saint-Petersburg. 
mammals. However, the major difference was clear dominance of common shrew in them. In our region, the numbers of this species are lower than those for bank vole. Most probably, common shrew has a higher tolerance level to urban load. Hence, bank vole is more affected by urbanization which is in accordance with previous data (Chernousova, 1996; Tikhonova et al., 2002, 2009; Zorenko \& Leonttva, 2003).

ACKNOWLEDGEMENTS. Authors express deepest gratitude to Roman Danilov for improving the English of early draft. This work was financially supported by Saint-Petersburg Scientific Center, Government of Saint-Petersburg and Program "Biodiversity" of the Russian Academy of Sciences.

\section{References}

Chernousova N.F. 1996. [The impact of urbanization on the community of small mammals of large industrial centre] // Ekologia. No.4. P.286-292 [in Russian, with English summary].

Fomushkin V.M. 1967. [Small mammals of forest-parks in Moscow and its epidemiological significance] // [Animals of Moscow and Moscow Province, its significance, protection and transformation]. Moskva: Moskovskoe Obshchestvo Ispytatelei Prirody. P.100-102 [in Russian].

Karaseva E.V., Tikhonova G.N. \& Stepanova N.V. 1990. [Small mammals in the vacant lots of Moscow] // Byulleten' Moskovskogo Obshchestva Ispytatelei Prirody. Vol.95. No.2. P.32-44 [in Russian, with English summary].

Klausnitzer B. 1982. Zur Kenntnis urbaner gradienten // Tagungsbericht 1. Leipziger Symposium Urbane Oekologie. Leipzig. S.13-20.

Kluchnik N.S. \& Starostina A.V. 1963. [Rodents of Leningrad] // Zoologicheskii Zhurnal. Vol.42. No.10. P.15541560 [in Russian, with English summary].

Magurran A. 1992. [Ecological Diversity and its Measurement]. Moskva: Mir. 184 p. [in Russian]
LiutovU.G., Vaschenok V.S. \& Shibalov V.A. 1977. [Distribution and density of small mammals in Leningrad in connection with its epidemiological significance]// Trudy Instituta Epidemiologii i Mikrobiologii. Vol.52. P.89100 [in Russian].

Poyarkov D.V. 1956. [Some data on ecology and distribution of rodents and insectivorous in Moscow] // Trudy Rostovskogo Gosudarstvennogo Nauchno-Issledovatelskogo Protivochumnogo Instituta. Vol.2. P.147-166 [in Russian].

Sukopp H. 1983. Öcologisch charakteristik von Grosstäden // Grundriss der Stadtplanung. Hannover: C.R. Vincentz. S.554.

Tikhonova G.N., Tikhonov I.A., Bogomolov P.L., Bodyak N.D. \& Surov A.V. 1997. [Distribution of small mammals and classification of undeveloped territories in Moscow] // Uspekhi Sovremennoi Biologii. Vol.17. No.2. P.218-239 [in Russian, with English summary].

Tikhonova G.N., Tikhonov I.A., Bogomolov P.L. \& Surov A.V. 2002. [Factors influencing the formation of the population of small mammals of the city cemeteries] // Zoologicheskii Zhurnal. Vol.81. No.5. P.617-627 [in Russian, with English summary].

Tikhonova G.N., Tikhonov I.A. \& Surov A.V. 2004. [Structure of rodent and insectivore populations in grassy biotopes of urbanized territories (by the example of Moscow)] // Zoologicheskii Zhurnal. Vol.83. No.11. P.13941403 [in Russian, with English summary].

Tikhonova G.N., Tikhonov I.A., Surov A.V. \& Bogomolov P.L. 2009. [Structure of small mammals community in parks of Moscow] // Ekologia. No.3. P.227-231 [in Russian, with English summary].

Vaschenok V.S., Liutov U.G. \& Shibalov V.A. 1973. [The dynamics of density of small mammals in Leningrad] // Trudy 14 Konferentsii Vrachey Leningradskoi Sanitarno-Epidemiologicheskoi Stantsii. P.130-131 [in Russian].

Zorenko T. \& Leonttva T. 2003. Species diversity and distribution of mammals in Riga // Acta Zoologica Lituanica. Vol.13. No.1. P.78-86. 